\title{
A nau dos insensatos
}

LUIZ BRAGA*

Em dezembro de 2005, depois de dois anos viajando como clandestinos, matriculamos nosso filho na Escola. ${ }^{1}$ Não que estivéssemos, nesses dois anos, escondidos no porão. Não. A nau é de insensatos generosos. Viajamos no convés, junto a todos, à brisa e a um ou outro tempo ruim. 0 relato que se vai ler, então, tem esse caráter de quase clandestinidade também: no mesmo barco, mas por ali, sem função específica alguma, sem responsabilidade (quase) nenhuma.

Portanto, é bom, desde aqui, deixar claro o que não se deve esperar deste pequeno relato: objetividade; análise crítica; isenção; imparcialidade. Um relato pessoal, somente.

Mas existe outra forma de se falar de uma experiência fundante?

\section{Conheci um lugar}

\section{A primeira vez que entrei na Escola foi em abril de 2004.}

Ana Elisa Siqueira ${ }^{2}$ caminhou comigo pelo pátio, pelas salas, foi me mostrando as paredes que já tinha derrubado. Claro que, de cara, simpatizei: no meio de tanta arrogância teorizada, de tanta hegemonia do pedagogês, não é brinquedo encontrar, assim, sem mais nem menos, uma adepta do demolicionismo. Então, Ana Elisa me contou do tempo ainda em que derrubava grades, assim: "A escola precisa ser bonita, precisa ser aberta, precisa mostrar que confia".

Fui pra casa contagiado, feliz da vida: daqui não saio, daqui ninguém me tira. Puxa, eu pensava, como são raros hoje os lugares que nos infundem leveza, essa sensação assim de êxtase jubiloso... Em casa, os meninos se espantavam: "Como assim, uma escola totalmente sem paredes? Nem telhado tem?" Não, vejam bem, derrubaram as paredes de algumas salas, que se juntaram, cresceram, claro que tem telhado, e algumas paredes também... 0 mais novo, cinco anos (na época), entre duas garfadas

* Luiz Braga é pai do Francisco, aluno da EMEF Desembragador Amorim Lima (luiz@musattiseguros.com.br). e desde o alto de sua simplicidade: "Mas isso não tem nada de mais, é assim mesmo que toda escola deveria ser, é assim mesmo que a minha escola é". 3

E eu pensava, mas não dizia (repare-se que estamos jantando, e eu temia fazê-lo engasgar com um tamanho excesso de realidade): "Tudo bem, meu chapinha, mas logo logo você vai ver o moedor de carne em que vai ser gentilmente inserido". Aos amigos doutos, eu punha uma pitadinha de erudição: "Aquilo é um platô, verdadeiro território desejante, essa Ana Elisa é a esquizoanalista dos sonhos de qualquer Deleuze e Guattari (mesmo que a dupla nem sonhasse), a paranóia ali é zero, uma profunda esquizoidice produtiva". E sarava. Fosse como fosse, era só uma justificativa, que a decisão já me tinha tomado: preparei minha trouxinha e fui pôr meu desejo ao abrigo daquele povo. O homem é um ser de necessidades que só se satisfazem socialmente, dizia Enrique Pichón-Rivière.

\section{Isso vem e não é de hoje}

\section{Você vê um barco assim, vento em popa, velas estufa-} das e, se já fez algum esforço em fazer andar um projeto, percebe que o trabalho não é de ontem, e que a coisa vem de longe. Se a Escola está em pé, mesmo depois de lhe tirarem as paredes, é porque tem alguma outra coisa sustentando. Você decida, mas eu sou de um tempo em que se acreditava em sustentações simbólicas. 0 esforço, hoje, de retomar o espaço público para o uso popular e público (Paulo Freire) exige caminhar no terreno frágil da utopia: de um lado, o ensino privado, bastante eficaz no ensinamento da realidade que vivemos, mas tristemente sucumbido a ela - em que falar de cidadania virou moda e é, portanto, tema de atenção numa aula por semana; de outro, o espaço público como espaço da degradação e do abandono consentidos (pela sociedade toda) - se o povo tem medo de sair à rua, a rua deixou de ser espaço público. 
$\mathrm{Na}$ Escola (antes que saiam por aí derrubando paredes), uma pequena história de dez anos de retomada:

a. Tirar as grades do pátio, primeiro. Uma corzinha nas paredes (a estética como índice civilizatório); um mural de azulejos pintados (pelos alunos); flores. Na medida do possível, a Escola se quer bonita. A professora Adelina e os Vigilantes da Natureza.

b. Cultura Brasileira. Conceição Accioly (foi fazer ciranda no céu - vai virar nome da nova sala de artes: presença que engendrou tanta boa mudança e lembrança que sustenta). Graça e o pessoal do Querosene. Mestre Alcides $^{4}$ e o pessoal da capoeira. Lydia Hortélio.

c. Envolvimento da Comunidade. Grupo de Teatro de Bonecos de Mães. Voluntariado. Abertura da Escola para atividades extraclasse. Sem o apoio das mães, pais, comunidade, a escola não se transforma. 0 Conselho de Escola como centro primordial do exercício da democracia e da participação.

d. Oficinas. Teatro. Circo. Dança. Artes Plásticas. Rádio. Horta. Capoeira. Cinema.

e. Interlocuções: convidar gente pensante, de fora, para vir açodar o acomodamento. Instituto Veredas. Instituto Pichón-Rivière. Yanina Stasevskas. Lenina Pomeranz. Ana Guerra. Rosely Sayão.

f. Festas. A Escola como palco de celebração. Festa Junina. Festa da Cultura Brasileira. Festa do Auto de Natal. Festa. A alegria compartilhada como índice civilizatório. 0 saber não é cinza.

g. Busca de apoios. Institucionais; individuais; estatal. Parcerias. Projeto Crer para Ver (por dois anos). Instituto Camargo Correia (por um ano). Contribuição sem ingerência - para isso existe o Conselho de Escola, para isso existe o Conselho Pedagógico: zelar pelas diretrizes, defender as linhas, entrincheirar cada palmo de terreno conquistado. 5

Era muito, mas era pouco. 0 diabo é que essa gente, quando se põe a desejar, desencontra qualquer limite...

\section{O Projeto}

\section{Ou seja: já naquele passado (a escola ainda tinha suas} paredes todas) estava bem inscrito o nosso futuro de hoje.

Num passado mais recente: em 2003, foi apresentado à Secretaria Municipal de Educação ${ }^{6}$ um projeto de assessoria externa. Reformulando profundamente o funcionamento da Escola, o Projeto foi aprovado pela Secretaria

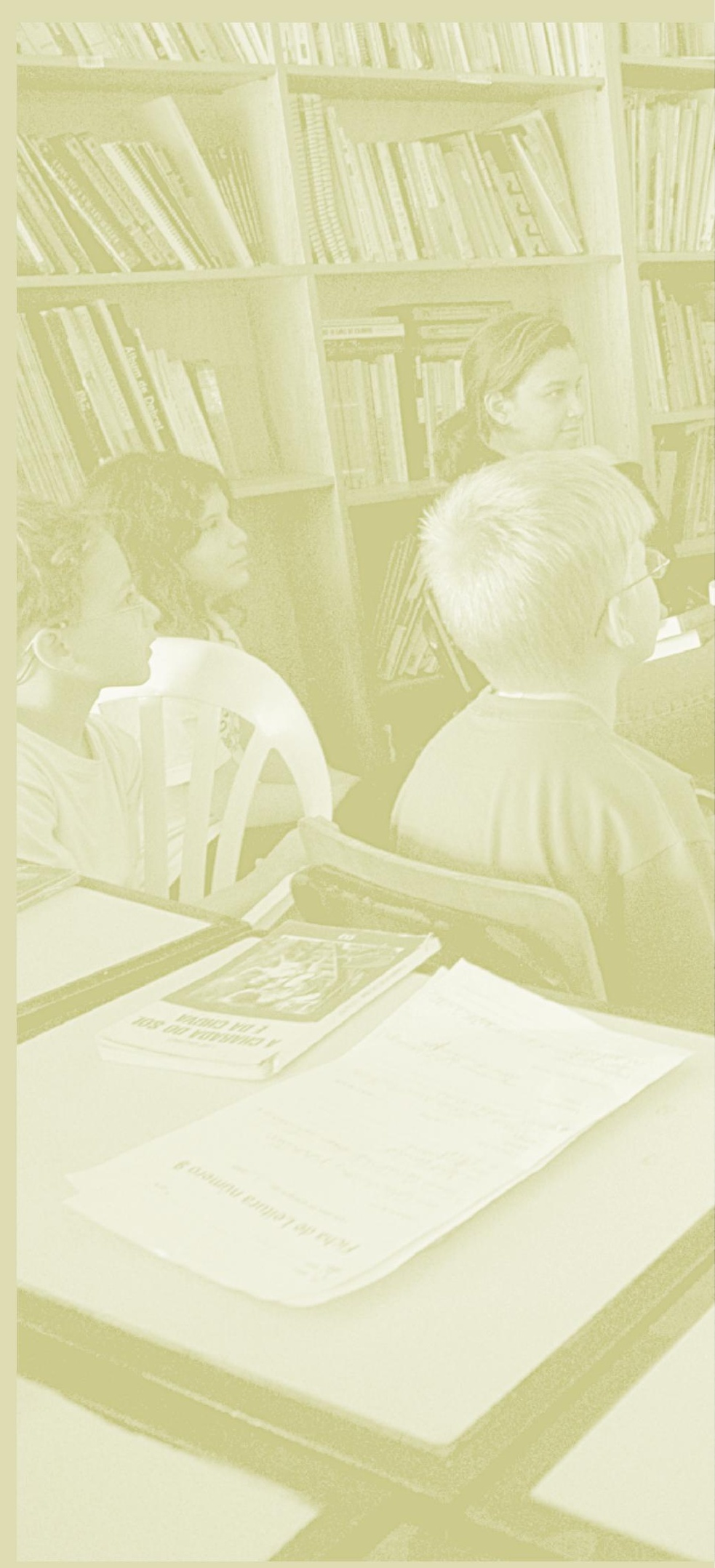




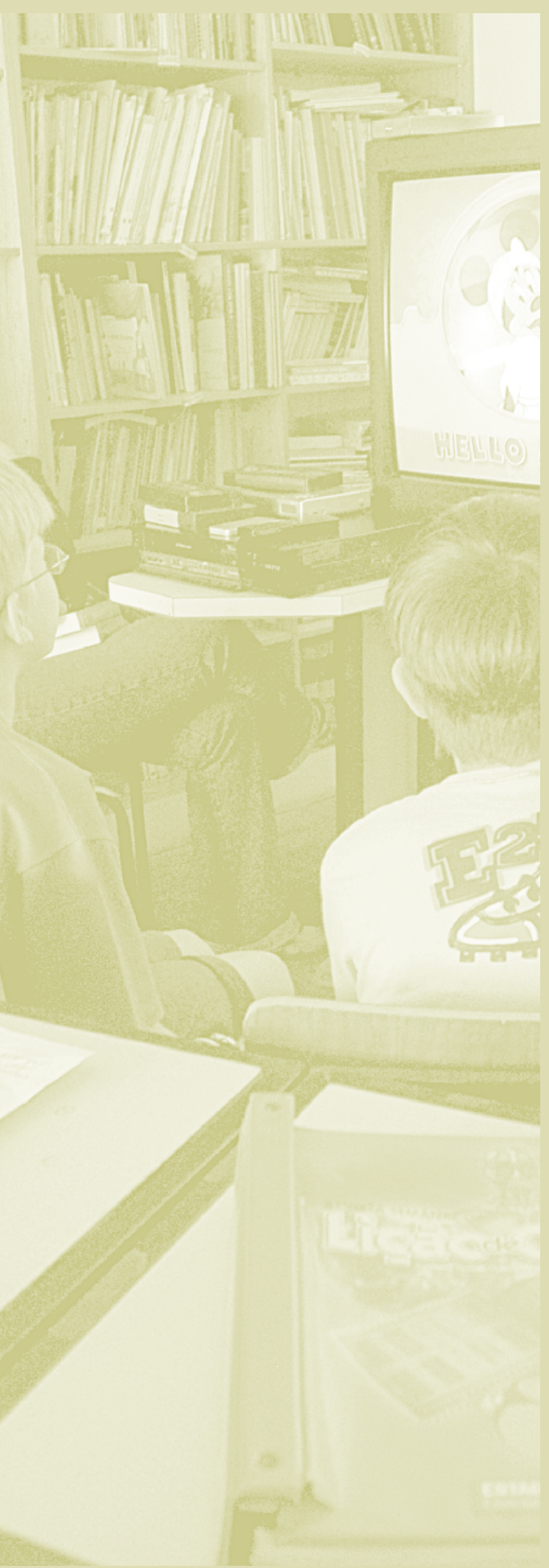

Municipal de Educação de São Paulo - SME, implementado desde o começo de 2004 e tem como objetivos 7 :

- proporcionar a formação global de todos os envolvidos;

- construir a autonomia moral e intelectual dos estudantes;

- garantir direitos: educação de qualidade, com período completo de aulas;

- incentivar o compromisso com o conhecimento;

- estimular e orientar o trabalho em grupo;

- promover a convivência com responsabilidade;

- assegurar o respeito aos tempos e processos individuais. ${ }^{8}$

Ou seja: uns bons hectares de terreno frágil da utopia.

Escandindo:

a. A utopia da construção da autonomia. A rima é pobre, mas o conceito é rico. A história é mais ou menos a seguinte, meu rapaz: você, pequeno aluno da Escola, tem, ao entrar, um bom punhado de roteiros esperando-o (eles são hoje 115). Encare-os como preciosos mapas, elaborados por um pesquisador ao mesmo tempo sonhador e criterioso. ${ }^{9} \mathrm{~A}$ diferença dos mapas dos piratas, em que no final você encontra um tesouro, nestes, a aventura não tem fim e você, em toda a parte, encontra tesouros cintilantes.

Nós estamos falando, meu filho, do Universo da Cultura do Homem, um universo fantástico de descobertas, aventuras, heroísmo e covardia, acertos e erros, alegria e dor. Esse universo nem sempre é bonito (você é tão jovem, mas já percebe isso, bem sei) e sempre merece o esforço de se tentar compreendê-lo. 0 mapa não é a aventura, assim como o roteiro não é a viagem. É tão somente um guia, uma pequena mostra das ilhas e praias que você poderá conhecer e algumas sugestões de bons caminhos que você pode trilhar para chegar até elas.

Nosso esforço (da Escola), vai ser todo no sentido de você não se ater somente ao guia, como o turista preguiçoso que somente olha e fotografa fachadas. Não. O convite é para você percorrer o caminho com calma, urgente sem pressa, como João Guimarães Rosa dizia de Deus (você vai poder conhecer Guimarães Rosa, meu rapaz, Manuelzão e Miguelim, Riobaldo Tatarana - há roteiros que te levarão às veredas e aos sertões todos das Gerais, tenha calma). Vai haver tempo para você parar e conhecer as pessoas: aprender sua música, sua dança, sua comida. Nestes oito, nove anos fundamentais, você vai conhecer um pouco do povo 
que habitava ancestralmente estas terras, ${ }^{10}$ e dos povos que a vieram depois habitar.

Como nem tudo são flores, você, muitas vezes, vai ter de atravessar desertos, vai se lanhar em muito espinho agudo e seco. Aprender requer também muito esforço, mas é muito bom ver como esse esforço deixa vocês bem felizes (você diz, muito orgulhoso, que já estava mesmo meio cansado da escola só de brincar). Outro dia, perguntei para o Matheus, seu amigo da $1^{\underline{a}}$ série, do que ele mais gostava e do que ele menos gostava na Escola. Sabe o que ele me respondeu?

"O que eu mais gosto é de aprender e fazer lição", com essas palavras, eu juro.

O que ele menos gosta, sabe o que respondeu? De quando você, meu chapinha, briga no recreio com o lan - o outro grande amigo dele (precisamos ter uma boa conversa). Ou seja, bom amigo esse que você tem, muito esperto: com sete anos, colocar o conhecimento e a amizade como as coisas importantes da vida, não é mole não - se não atrapalharem muito, o rapazinho vai longe.

Porque eu quero lhe dizer mais uma coisa: você vai notar que nós, adultos, somos dúbios, ambíguos, dizemos muito que queremos que você aprenda, mas agimos muito no sentido de mantê-lo ignorante e dependente (assim os espertos seremos sempre nós).

b. A utopia da inclusão. 0 nome não é bom, bem sei. Falar em inclusão já aventa um universo de exclusão que, ele sim, precisa ser erradicado. Mas o que se quer é só contar de um certo esforço consciente e que se pretende seja de toda a Escola: alargar os umbrais da convivência à largura de qualquer diferença. Claro que isso, sendo um direito, só é passível de acontecer na escola pública, tão infensas estão algumas escolas privadas ao reconhecimento de certos direitos bastante elementares ${ }^{11}$ (e é por isso, acima de tudo, que a boa escola, a melhor escola há de continuar sendo, e voltar a ser, a escola pública). Quatro psicólogas auxiliam a Escola neste esforço. ${ }^{12}$

c. A utopia da participação da comunidade. Há quem pense que a participação da comunidade (muitas vezes voluntária) é um produto dos liberalismos, um esforço que acaba por incorrer num pretexto de desobrigação do Estado. Dos vários modos de defesa do imobilismo, esse é o mais canhestro: tem certo apelo ideológico, e é, muitas vezes, defendido por pessoas de bem. Nós vivemos uma guerra - é bom que perce- bamos de uma vez. Já bem o disse o professor Paulo Freire: talvez até possa acontecer que uma mudança da escola não implique uma transformação social - nenhuma transformação social é, no entanto, possível se não passar por uma transformação da escola. A Escola é nossa trincheira e, como diz Paulo Leminski: "En la lucha de classes, todas las armas son buenas: piedras, noches, poemas".

Porque o descaso com a educação não é questão só de Estado, esse ou aquele governo - um milhão de alunos do ensino municipal de São Paulo sem aula é notícia de quarta página do caderno local dos principais jornais. De tão banal e evidente, a verdade dá vergonha de ser dita: a sociedade (não só a constituída como Estado) não quer, não tem o menor interesse em ter uma escola pública de qualidade.

Não entra no rol das preocupações das pessoas cujos filhos estão nas escolas privadas que a escola pública seja ruim - isso é da Natureza, isso está posto como o dia que nasce e morre. A escola pública é ruim é verdade tão aceita e incontestada como: anoitece. A preocupação crescerá, aí sim, à medida que tivermos uma escola pública de qualidade. O verdadeiro ato revolucionário no Brasil de hoje é termos um ensino público, popular, universal, de qualidade - e isso não se consegue flanando nas teorias, nem nas ideologias.

Tente não pensar a Escola como uma ilha, e sim como uma trincheira - abaixe a cabeça e proteja-se, e tente, por favor, não acertar o tiro no próprio pé (inimigos não nos faltam). Hoje, vários projetos, já implementados ou em fase de implementação, são coordenados total ou parcialmente por pais ou voluntários:

- jornal, coordenado por pai de aluno;

- portal, coordenado por grupo formado por pais, funcionários, empresa parceira;

- Estação Butantã - vasto projeto estudando a história, geografia, ocupação e urbanismo do Bairro do Butantã, coordenado por pais e moradora do bairro;

- Meus pais leram para mim - projeto de empréstimo de acervo e incentivo aos pais a lerem para seus filhos, coordenado por professora e mãe;

- Grupo de preparação das Assembléias de Alunos, coordenado por pai e mãe;

- Grupo de Cinema, coordenado por educadora voluntária;

- educadora Thereza Pagani, a Therezita, uma vez por semana na Escola; 
- professor José Pacheco - membro do Conselho Pedagógico da Escola;

- professora Lenina Pomeranz - auxiliando na formatação de projetos e na ONG;

- forno caipira construído por pais e funcionários (aos sábados e domingos).

d. A utopia da construção da cidadania por meio da prática democrática. Em primeiro lugar, é preciso destacar o Conselho de Escola. De formação paritária sete representantes dos professores; sete, dos pais; sete, dos funcionários; e sete, dos alunos - é o palco preferencial da construção democrática. É vital por vários motivos:

- Ensina-nos a todos - professores, pais, funcionários e alunos - a vivência democrática: a necessidade de defender lógica e coerentemente nossos pontos de vista; a necessidade de construir consensos que permitam avançar em meio às divergências.

- Ensina-nos a pensar na e a escola que queremos. Aproxima o horizonte do desejo a uma distância tangivel, e nos faz sentir agentes de transformação, e não meros objetos de políticas e ações que nos são transcendentes. Por outro lado, depara-nos com os limites sempre presentes (em nós mesmos e na realidade), exorta-nos para o esforço de superá-los e, finalmente, desarticula o discurso fácil de culpar somente entes externos (mesmo que também culpados).

- Principalmente: obriga a nos defrontarmos. Criados que somos no discurso da complacência, da polidez e da subalternidade, desacostumamos de nos dizer verdades. 0 Conselho de Escola pode, e deve, tornar-se então o instrumento de encarnação e materialização do discurso: por favor, diga-me verdades inscritas em sua própria carne; por favor, ao falar-me, olhe-me nos olhos; por favor, não me venha com o discurso da autoridade do saber (estudei e, portanto, sei), da autoridade do poder (aqui mando eu), da autoridade do privilégio travestido em direito (falto porque a lei me permite). Por favor. A escola, como tantos outros lugares, desencontrou e desconstruiu a possibilidade de diálogo (uma conversa entre iguais): o professor, principalmente (como categoria), cerrou fileiras na defesa de seus direitos e somente consegue articular (como categoria) o discurso do corporativismo. ${ }^{13}$

\section{Tarefa hercúlea: construir pontes sobre o imenso desvão que se formou entre os pais e os agentes de
educação, cuja relação se foi
tornando hostil e agressiva,
de ambos os lados.}

Além disso, não é só o direito a faltar que faz com que o professor que leciona nas redes pública e privada falte naquela e não falte nesta, há também um preconceito: a convicção de que ao aluno da rede pública está de bastante bom tamanho o pouco que se the dê (pois se é dado...). Não há diálogo: o professor, identificado não se sabe exatamente com o quê, trata a clientela da escola pública com a empáfia e o descaso com que as elites tratam as classes subalternas: estão convictas de que não lhes devem explicações.

Aos pais, cabe então o aprendizado (também longo e custoso, porque também nós somos vítimas de preconceito) de que a escola de qualidade é um direito não nosso, mas, principalmente, dos nossos filhos - é então um dever nosso lutar por um ensino de qualidade, e exigir dos professores compromisso e seriedade. ${ }^{14}$ Cabe, pois, ao Conselho de Escola, ser o palco da requalificação do diálogo, da construção de um discurso forte de cobrança mútua, constante e implacável cobrança da ação encarnada, da prática comprometida - e de repúdio aos discursos e práticas escamoteadoras, enganatórias, sabotadoras. Cabe ao CE ser o palco de uma tarefa hercúlea, importantíssima, sem a qual malogrará qualquer política que vise melhorar o ensino público: construir pontes sobre o imenso desvão que se formou entre os pais e os agentes de educação, cuja relação se foi tornando hostil e agressiva, de ambos os lados.

As grandes transformações da Escola foram muitíssimo discutidas no Conselho de Escola, e consolidadas na aprovação do Projeto Político Pedagógico ${ }^{15} \mathrm{e}$ do Regulamento Interno - que cria novos e importantes instrumentos de gestão democrática, e dos quais cabe destacar:

1. O Conselho Pedagógico. Formado pela diretora da

EMEF, dois coordenadores pedagógicos regimentais, três professores escolhidos por seus pares, dois educadores convidados e um representante dos arte-educadores, tendo a participação de 
duas mães na condição de ouvintes. O Conselho Pedagógico é o responsável pela criação e implementação dos dispositivos e práticas pedagógicos, no sentido da melhor implementação do Projeto. Favorece enormemente que cada segmento venha a ter uma visão mais global e abrangente da Escola, e que se implique, e a seus pares, com o Projeto de forma integral;

2. O Conselho de Gestão Financeira. O coletivo da EMEF aprender a gerir e administrar seus recursos de forma democrática e transparente não é tarefa desimportante. 0 problema do ensino também é um problema de gestão - financeira, inclusive. 0 aprendizado e a experiência darão confiança na luta por uma crescente autonomia.

e. A utopia do conhecimento solidário. Você já se senta em grupos de cinco alunos, ainda na sala pequena e ainda com uma única professora, a Cleide (você é um cara de sorte), e uma estagiária - afora, é claro, as oficinas que você faz em outros espaços. Logo que você estiver lendo mais fluentemente, entendendo melhor como funciona a barafunda toda, vai para o salão grande trabalhar com os tais roteiros (isso é logo, não se preocupe, você cresce bem mais rapidamente do que imagina...).

O grupo, você já sabe para que serve - a Cleide deve falar bastante disso, eu acho - pois outro dia você me falou que ia pedir para o Caio, que já sabe, lhe ensinar letra cursiva. Você diz que vai ensinar matemática para ele - “Em matemática, eu sou muito bom”, você falou. Então, é bem isso, eu penso que o começo de quase tudo está aí: uma auto-avaliação espantosamente consciente (isso eu sei, isso eu não sei), e uma crença no poder da solidariedade (isso eu sei e posso ensinar; isso eu não sei e preciso encontrar quem me ensine).

Mas o conhecimento solidário não é só isso. Há também o que alguns meninos, que estudam e estudaram em outras escolas, estão vindo fazer, o que alguns pais e outros adultos estão vindo fazer. ${ }^{16}$

E há, ainda, o que o Geraldo Souza chama de Educador Público - a mais importante, e utópica, de nossas utopias.

f. A utopia do advento do Educador Público. O método de pesquisa em grupos nos salões, que a Escola utiliza, é uma prática que não garante, por si, qualquer melhora do ensino - evidentemente. Poderão alguns argumentar que o método é, na escola, o que me-

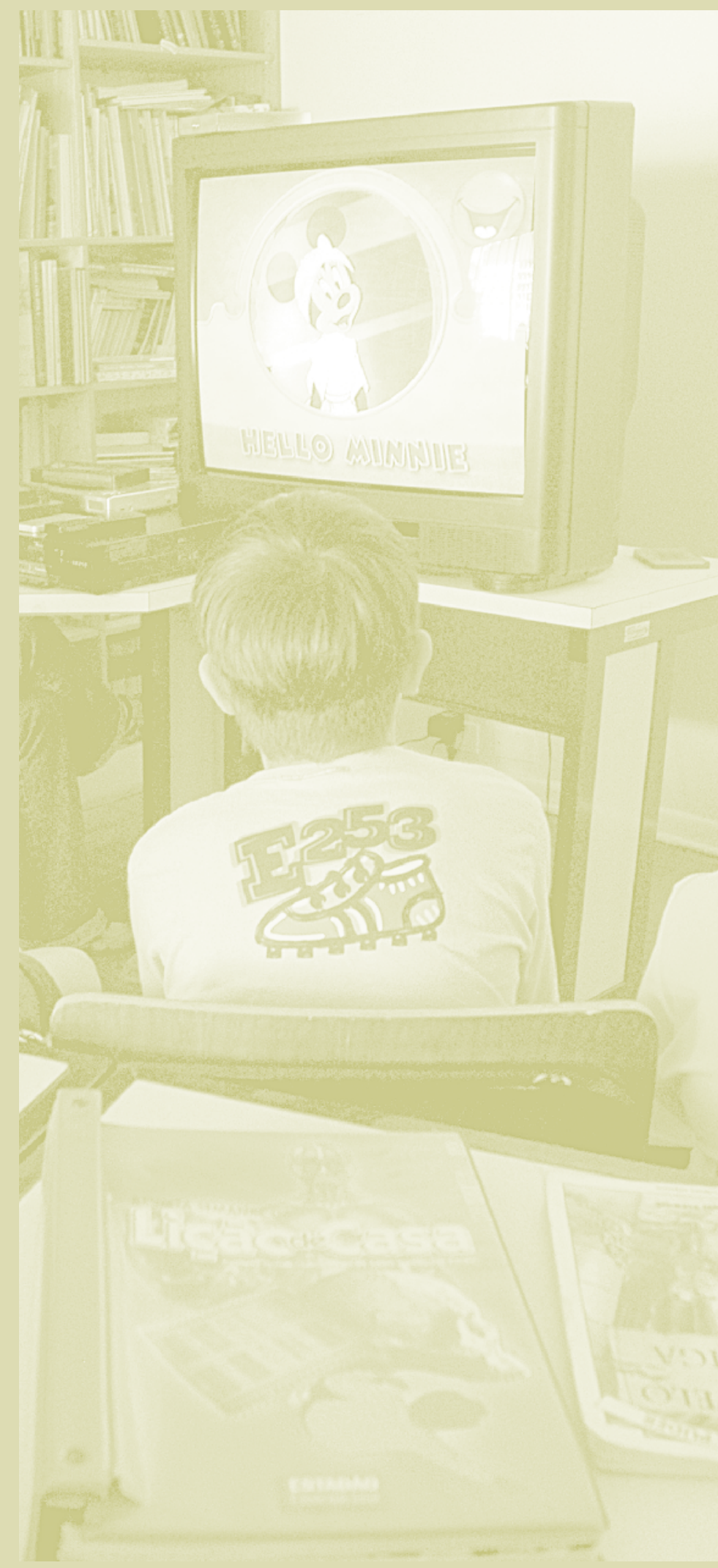


nos importa - e estarão, sem dúvida, cobertos de razão. Há bons, excelentes professores, com métodos que se poderia chamar antiquados, assim como é comum travestir-se o descompromisso e o desinteresse com roupagens ditas modernas - o trabalho em grupo e o incentivo à pesquisa sendo algumas delas. Se isso é verdade, também é bastante verdade que, na Escola, o método não é aleatório, nem bem menos fruto de uma qualquer inconseqüência, sendo fundamental no processo de construção da escola que queremos.

0 método de trabalho na Escola favorece o advento do Educador Público das seguintes maneiras:

- O professor, hoje, por mais capaz que possa ser, viu sua função distanciar-se a tal ponto do papel de Educador, que já quase não o vislumbra. E isso por vários motivos:

1. em primeiro lugar, pelo advento das especializações psicopedagógicas, não é mais função do professor:

- orientar (há um orientador para isso);

- falar de questões relativas à subjetividade (há um psicólogo para isso); ou

- falar de uma dificuldade qualquer diante do aprendizado (há a psicopedagoga para isso).

2. em segundo lugar, a própria forma como a escola se organiza obriga o professor a se ater, e se preocupar, com uma turma, uma aula, uma matéria. Está o professor dando sua aula e pouco se lhe dá se a classe vizinha vagueia no pátio pela falta de um seu colega: isso não lhe diz respeito, absolutamente. 0 convite que a escola faz ao professor não é para olhar o aluno, para se preocupar com ele, e sim para se ater a um conteúdo e a um compromisso específicos - a escola de hoje é um espelho despedaçado em que o professor, por melhor que seja sua boa vontade, não se pode enxergar, pois não enxerga o aluno em sua totalidade. 0 professor é hoje um fragmento, e um fragmento nunca vai ser um Educador.

3. o professor trabalha sozinho entre díspares, dentro de sua sala, e essa é uma função (no sentido teatral mesmo do termo) pobre: os palhaços, que são sábios, só muito raramente atuam sozinhos. A solidão amesquinha a alma mais nobre - perde-se em elã o que se ganha em soberba.

4. então, o professor vai se agarrar à sua moldura e exigir respeito - porque sabe mais, porque pode mais - mas terá com esse fragmento de aluno um diálogo impossível: o aluno que ontem vagava sem aula pelo pátio sabe que esse professor viu e nada fez; o aluno, que está sem aula de outra disciplina, vê que esse professor nada faz: o aluno, que não é bobo (e ainda não aprendeu a ser cínico), sabe que o professor se preocupa com o silêncio na sua aula, com a disciplina na sua aula - o professor não se preocupa com ele - então, por que respeitá-lo?

- A diretora, os orientadores pedagógicos, os auxiliares de período e os agentes escolares têm, na Escola, o estatuto de educadores. Isso significa tanto um reconhecimento formal, quanto a imersão em práticas de "ensinança” mesmo - tutoria inclusive. Muitos de nós estranhamos essa posição: tanto mais quanto mais nos prendemos às formalidades. Um agente escolar tem formação para dar oficina de matemática? Um agente escolar que conhece as quatro operações teria? Um que pesquise, ouse aprender, experimente. Essa é a dádiva do processo: você conhece pessoas que sempre são mais (e, às vezes, menos) que suas supostas qualificações.

- Nós, pais e mães, zelosos que somos, aprendemos a amar nossos filhos, mas temos naturalmente nossas dificuldades em amar a criança, em sua totalidade. Daí a importância do grupo, e do coletivo da Escola: há pessoas, nele, com grande sentimento do mundo, com as quais aprender. Cada um tem suas dificuldades específicas, seus pontos cegos, que outros haverão de poder iluminar. O pai ou a mãe, tendo adentrado o espaço da escola, precisa aprender a se tornar Educador, e não de seu filho somente. A amizade e o respeito aos nossos grandes amigos só se materializam quando temos liberdade para dar, nos seus filhos, a bronca que daríamos no nosso; para dar, a seus filhos, o incentivo e o reconhecimento que daríamos ao nosso. Isso, um dia, na escola - e isso, um dia, fora da escola também.

- O aluno, à medida que se torna agente, à medida que se apossa da Escola como sua, torna-se, também ele, Educador. $O$ aluno cada vez mais aprenderá que a cidadania é a exigência de respeito: para com sua história, para com seu corpo, para com os seus direitos - a escola entre os mais preciosos. 0 aluno cada vez mais saberá dizer ao outro aluno: não estrague a minha escola; cada vez mais saberá dizer a nós, adultos: respeite a minha escola. 


\section{E, por que não, um tutor?}

\section{E aqui caberia destacar o espaço da tutoria como um} dos instrumentos fundamentais para o advento do Educador Público integral, e do aluno integral - adventos simultâneos e inseparáveis, pois não se vai nunca atingir a integralidade na formação do aluno, sem atingir também a do educador. Atendo-se semanalmente, durante todo um período, a um pequeno grupo de alunos (15, no máximo), o educador pode acurar sua escuta, aprofundar seu olhar, reenquadrar sua conduta.

O tutor - como na botânica, em que o tutor apóia e esteia o novo broto e o novo ramo - vai semanalmente verificar o trabalho realizado, propor reparos e aprofundamentos, sugerir os novos passos para a semana que se vai começar. Vão poder estabelecer, tutor e aluno, uma relação que ultrapasse o mero verniz das conveniências e das aparências.

Em suma: se a metodologia aplicada na Escola não é a garantia, é uma engenhosa e poderosa contribuição à construção da escola democrática e cidadã que almejamos. Se, como bem sabemos, a distância até ela é ainda bastante longa (...tanto mar, quanto mar...), pois que demos somente umas poucas braçadas, cada vez vai-nos ficando mais claro para onde remar - o que, retomando a alegoria do título, faz da Escola uma nave bastante distinta da stultifera nave medieval, que vagava sem rumo, perdida nos mares.

\section{Notas}

1 A Escola aqui é a EMEF Desembargador Amorim Lima, no Butantã, em São Paulo. Este depoimento foi escrito em abril de 2006.

2 Ana Elisa é a diretora e a grande responsável pelas transformações na Escola.

3 Ele estudava na Tearte, mas isso é outra história.

4 Numa entrevista que as crianças fizeram com Alcides, foi-lhe justamente perguntado: “Como é que se faz para virar mestre?” Resposta singela, mais ou menos esta: "Propriamente não se faz - começam a lhe chamar mestre, aqui e ali; não é você que escolhe, mas os outros que o elegem...”. Simples assim, como tudo que faz sentido.

5 Não se iluda com o caos: no meio da barafunda toda, o pessoalzinho sabe bastante bem o quer e como quer. Não se iluda: além de agogôs e chocalhos coloridos, também há flechas e lanças no paiol.

6 Maria Aparecida Peres era secretária, à época.

7 Tendo recém-visitado a Escola da Ponte, e notando o entusiasmo da comunidade da Amorim Lima pelo Projeto Fazer a Ponte, a psicóloga Rosely Sayão, a pedido do Conselho de Escola, formulou e apresentou, em setembro de 2003 , uma proposta de assessoria, no sentido de se ir implantando, na Amorim Lima, dispositivos inspirados naqueles da escola portuguesa (consulte www. eb1-ponte-n1.rcts.pt ).
8 Passados 30 anos desde o advento das "escolas experimentais" dos $1970 \mathrm{e}$ 1980 , as que sobreviveram foram enchendo de tal modo o bucho de conceitos e "experiência acumulada" que hoje voam baixo como galinhas. De tudo, talvez se possa acusar esse bando de insensatos - não se poderá, contudo, acusá-los de fazerem baixas suas expectativas.

90 pesquisador Geraldo Tadeu Souza elaborou os roteiros e trabalha enormemente em sua implementação. Os Roteiros Temáticos de Pesquisa são concebidos segundo a Teoria Dialógica da Linguagem do Círculo de Bahktin, e se apóiam nos livros didáticos e paradidáticos fornecidos pelo Ministério da Educação, por meio do Programa Nacional do Livro Didático. Uma publicação que conterá o conjunto completo de roteiros, bem como uma explicação mais pormenorizada dos métodos de sua concepção e implementação, de autoria do Prof. Geraldo, e com os direitos autorais gentilmente cedidos à APM da EMEF Desembargador Amorim Lima, está no prelo, e poderá ser conseguida na Escola dentro em breve.

10 Estamos construindo, na Escola, com a supervisão e colaboração dos índios guarani da aldeia Tenondé-Porã, em Parelheiros, São Paulo, uma edificação nos moldes da Opy Guasu (Casa de Reza) desse povo. Sagrada para eles, pois a Opy Guasu é o espaço privilegiado de troca cultural, o local primordial de preservação de suas tradições e de sua cultura, a construção na Escola assume também um estatuto que se poderia chamar sagrado: um local para praticar o respeito a todas as culturas, por meio da música, da dança, da “contação" de histórias. E sagrado também porque demonstra nosso respeito e nosso afeto pelo povo guarani.

11 Para alguns outros direitos, no entanto, a observância é ciosa: o direito de submeter os alunos de seis e sete anos a um exame vestibular, por exemplo. Há escolas em São Paulo em que o estrábico não entra nem com mandado de segurança. Bom, exagero, talvez, quanto ao estrabismo.

12 São elas: Simone de Camargo Silva, Evelyn Madeira, Larissa Patty Gomes de Jesus e Ana Paula Musatti Braga.

13 O mal acomete também enormemente os professores comprometidos, sérios: cumprem valorosamente suas funções, mas lhes pareceria suprema traição levantarem-se contra os ineptos que não a cumprem - como se o descompromisso de alguns não fosse responsabilidade de todos.

14 Em artigo, na Folha de S.Paulo, certa colunista identificou a presença dos pais na escola como um dos obstáculos ao avanço do ensino - fazendo graça, afirmou que na escola de hoje era preciso "des-envolver" os pais. A colunista obviamente confunde envolvimento com o vínculo essencialmente mercadológico que certas escolas estabeleceram com os pais - muito mais por culpa delas do que deles. Como não deixa claro de que escola fala, vamos dar-lhe o benefício da dúvida e imaginar que não seria da escola pública - o que, obviamente, daria à afirmação estatuto de estultice completa.

15 A íntegra do Projeto Político Pedagógico da EMEF Desembargador Amorim Lima pode ser encontrada no endereço www.amorimlima.com.br.

16 Noutro dia o João, (meu filho mais velho, de 11 anos, que não estuda na Escola), ouvindo a mãe entusiasmada contar que a Neiva Brandão, experiente professora de educação física, ia à Escola tentar ajudar nos trabalhos corporais, disse: "Mas essa escola parece uma cidade proibida, um lugar de fugitivos; alguém sabe educação física e vai ensinar, outro sabe outra coisa e vai fazer outra coisa...”. Um quilombo de libertos, é uma imagem de que gosto. 
